\title{
Dimensiones de los Derechos Humanos en el Cambio Climático: Sinergias y Salvedades
}

\author{
Human Rights Dimensions in Climate Chamge: \\ Synergies and Caveats
}

\author{
Dr. Juan Auz Vaca \\ Investigador Jurídico, Fundación Pacha Mama
}

Artículo Original (Investigación)

RFJ, No. 1, 2017, pp. 137-162, ISSN 2588-0837

RESUMEN: El cambio climático enlaza serias amenazas al disfrute de los derechos humanos en todo el mundo, especialmente en los sectores más vulnerables de la sociedad. Esto implica que los Estados tienen deberes positivos y negativos al proteger los derechos sustantivos y procesales en este contexto. Sin embargo, existen varios desafíos legales cuando se utilizan los derechos humanos para abordar los efectos del cambio climático. Dichos desafíos son en su mayoría palpables, no sólo en los casos nacionales y regionales de derechos humanos relacionados con el cambio climático, sino también en las medidas de mitigación del cambio climático como una amenaza latente para los derechos humanos.

PALABRAS ClAVE: Cambio Climático, Derechos Humanos, Derecho Ambiental, regulación regional, regulación

ABSTRACT: Climate change poses serious threats to the enjoyment of human rights around the world, particularly for the most vulnerable members of society; hence, states have positive and negative duties when safeguarding substantive and procedural rights in this context. However, there are several legal challenges when human rights law is used to address the effects of climate change. Said challenges are mostly tangible, not only for climate change-related cases in domestic and regional human rights law situations, but also as regards climate change mitigation measures as a potential threat to human rights.

KEY WORDS: Climate Change, Human Rights, Environmental Law, regional regulation, regulation. 


\section{INTRODUCTION}

Within International Law Human Rights has arisen as an anti-thesis to international political catastrophes, aimed at protecting those most vulnerable by alleviating international distress through the use of an ethical discourse in order to seek remedial measures and prevent further harm. It is a form of reinventing humanism to "self-impose disaster behind" (Moyn, 2010, 87). The most obvious example of this interpretation is the creation of the Universal Declaration of Human Rights, born after World War II. In this context, human rights could be also deemed a counter-narrative, a tool for empowerment and an instrument to allow for the balance of power.

The conclusion of this historical lesson is that human rights violations are caused by a plethora of reasons. Under this logic, it would not be out of context to view Greenhouse Gas (GHG) emissions, which cause climate change, as a source currently impacting the enjoyment of human rights for millions of people around the world (OHCHR, 2009, 16). This confirms that a global concern of worldwide consequences should be addressed by all states, by adopting both preventive and corrective measures in order to fully tackle the problem. This focus is parallel to other global-scale problems such as slavery, torture and genocide -which were dealt with by adopting international treaties, prohibiting these practices, now considered as erga omnes obligations- (Shaw, 2008, 275), not only in the sense that major political volition is needed in order to see significant results, but also because viewing climate change as a human rights problem might provide "greater moral urgency and appeals to an additional constituency beyond environmentalists" (Bodansky, 2010, 518).

It should be taken into consideration that enormous international efforts have been made so far for tackling climate change; from the universally endorsed UN Framework Convention on Climate Change (UNFCCC), to the Kyoto Protocol and the numerous decisions by the Conference of the Parties of both instruments. However, a human rights approach to this global issue is still considerably lacking (S. McInerney-Lankford, M. Darrow and L. Rajamani, 2011, 8).

This gap, however, is being filled with important but relatively new discussions being engaged in by academics (S. McInerney-Lankford et al., 2009), the Human Rights Council (HRC, 2008; HRC, 2009; HRC, 2012; HRC, 2014; HRC, 2015) and its Special Procedures (UNGA, 
2009; HRC, 2014), the Office of the High Commissioner for Human Rights (OHCHR, 2009), the World Bank (S. McInerney-Lankford et al., 2009), to some extent regional human rights mechanisms (IACHR, 2006) and more recently, with the ratified Paris Agreement (UNFCCC, 2016).

Virtually all of these academic commentators and institutions, based mostly on the scientific findings of the fourth and fifth Assessment Report of the Intergovernmental Panel on Climate Change (R.K. Pachauri and A. Reisinger, 2007; R.K. Pachauri and A. Reisinger, 2014), have stated that there is almost no trace of doubt that the effects of climate change have a detrimental effect on substantive rights, such us inter alia, the right to life, health, safe drinking water and sanitation, adequate food, adequate housing, self-determination and the right to development (HRC, 2014). Most of these rights, which are classically associated with Economic, Social and Cultural rights - which give rise to the positive and negative duties of the state in ensuriing that their citizens have their basic needs fulfilled - (Fredman, 2008) are enshrined in various international and regional human rights instruments, with the International Covenant on Economic, Social and Cultural Rights (ICESCR) being the most globally endorsed of these (http://indicators.ohchr.org). In addition to the aforementioned category of rights, procedural human rights are also at stake in the context of climate change: in the sense that the importance of guaranteeing the rights of access to information, participation and consultations in relevant decision-making processes and judicial appeals is central to the protection of other rights (ECtHR, 2005; Aarhus Convention, 1998; Rio declaration, 1992).

The underlying issue is that while both sets of rights-substantive and procedural-entail duties for states, it is still not sufficient to evidence the embodiment of these duties under the light of climate change and the extent of differentiation with other environmental duties. This theoretical legal implication becomes more complex when practical shortcomings appear, such as the apparent incompatibility of climate change-related bother to people and property in relation to the nature of the interpretation and application of human rights law. Moreover, both kinds of hindrances have different outcomes when applied in the context of international law, which may be distinct from domestic fora. Another relevant issue is that, following the emergence of the climate regime, many of the decisions made by the Conference of the 
Parties (COP) to mitigate negative effects have also had repercussions on human rights around the world; especially in local communities.

It is worth mentioning that apart from the petition of the Inuit -a Canadian indigenous- which was presented before the InterAmerican Commission of Human Rights in an effort to push the US to ratify the Kyoto Protocol as a measure to reduce the negative effects of climate change which have repercussions in the enjoyment of their human rights (S. Watt-Cloutier, 2005), there is no other international case where climate change and human rights are so firmly intertwined, demonstrating the practical innovation of this approach in relation to the climate change regime's years of existence.

With that in mind, the first part of this essay will briefly address the effects of climate change on the enjoyment of human rights, emphasizing the key point brought up by the European Court of Human Rights (ECtHR) in the Öneryildiz v. Turkey case (ECtHR, 2004), with respect to the indistinctive use of the positive and negative duties of states when safeguarding substantive and procedural rights in the context of climate change. The second part will touch upon the legal challenges of utilizing international human rights law to address the effects of climate change, bearing in mind the recognition of the International Court of Justice (ICJ) with respect to the general obligations of states to prevent environmental harm to other states as part of the corpus of international law relating to the environment (ICJ, 1996). The third part will cover the approaches of human rights law to address climate change related cases in domestic and regional human rights law situations. The fourth and final part will address the issue of climate change mitigation measures as a potential threat to human rights, especially the case of the mechanism to "Reduce Emissions from Deforestation and Forest Degradation, and foster Conservation, Sustainable Management of Forests, and Enhancement of Forest Carbon Stocks" (REDD+) in local communities.

\section{CLIMATE CHANGE AS A MENACE TO SUBSTANTIVE AND PROCEDURAL RIGHTS}

The International Covenant on Civil and Political Rights (ICCPR) and the ICESCR, regarded as international human rights law "frameworks", alongside regional human rights treaties such as the African Charter on Human and Peoples' Rights, the European 
Convention on Human Rights and the American Convention on Human Rights, establish substantive and procedural duties on states, which are comprised of three responsibilities: to respect, to protect and to fulfil rights (Haas, 2014).

The obligation to respect is considered "negative", which basically means that states must abstain from intervening in activities that might harm human rights. One good example of this obligation is that states should not be involved in acts conductive to violation of the right to life. Conversely, the obligations to "protect" and "fulfil" are related to positive duties, which means that states should take measures, policies, legislation and resources to safeguard rights-for example, laws to encourage education programs, public healthcare policies and so forth. Substantive and procedural rights therefore must be safeguarded through both positive and negative duties from states.

When analyzing procedural rights violations in the context of environmental damage, states not only have the duty to refrain from actions that could imply a risk to human rights, but generally, they also have the duty to establish legislative or administrative measures to regulate or control the activities of private and public actors within their jurisdictions in order to avoid potential environmental harm. For instance, the duty to regulate activities of non-state and state actors by requiring the completion of an Environmental Impact Assessment (EIA) -which generally entails a participatory phase-is considered as international state practice in order to determine all the factors that a certain activity implies in terms of potential harm to people, property and the environment (Okowa, 2000: 132). When states argue that they have complied with this duty before a human rights court, it is most likely that the court will either partially or totally redeem the state from a wrongdoing.

This view is supported by the judgment in Taskin and Others $v$. Turkey, which stresses that investigations, studies, public access to information for such investigations, and judicial or administrative recourses to appeal decisions must be in place at the time of deciding issues of environmental and economic policy which "might damage the environment and infringe individuals' rights” (ECtHR, 2005).

Article 2 of the Aarhus Convention and Principle 10 of the Rio Declaration, likewise resonate with the aforementioned duty of states to fulfil the right of access to information, participation in 
decision-making and access to justice in environmental issues without any kind of discrimination.

These procedural rights are also stressed in article 6 of the UNFCCC, stating that parties to the convention shall promote and facilitate, at national, sub-regional and regional levels, public access to information and public participation regarding the effects of climate change and measures to address it.

Procedural rights should thus also be respected in the climate change context by allowing constituents full access to information regarding climate change. This means that if a country is part of the climate change regime -by having ratified the UNFCCC-, it may be in non-compliance concerning its legal obligations as a result of not deploying any sort of measures to ensure public dissemination and participation regarding climate change and its effects. However, what it is still problematic is that this exercise might be limited to a domestic forum only, and even there, the cause that triggers the petition could be difficult to determine. Also, it is quite unrealistic that someone sue a state for not having provided information about climate change and its effects, while at the same time using the same information which is claimed to be absent.

There might be, however, an opportunity to assert that procedural rights are not being respected, since adequate measures to participate in the decision-making process are not being entirely implemented. The problem here is the determination of what should be considered a mechanism for participation. Here, the report on Climate Change and Human Rights elaborated by the OHCHR (2009), sheds light on the matter by saying that "adequate and meaningful consultation with affected persons should precede decisions to relocate people away from hazardous zones." This interpretation sets an obligation regarding consultations in the event of an emergency adaptation measure; in this case, relocations due to a potential catastrophe attributed to climate change. Hence, were States to foresee the potential risk of a climate event in a specific location without conducting a good-faith consultation process, the risk of breaching international human rights law obligations would be highly likely, especially if this hypothetical climate event damages property, degrades the environment and causes loss of life. 
The situation is slightly more complex within the realm of Economic, Social and Cultural rights than in Political and Civil Rights, since most of these types of rights demand several actions that states should address, entailing multiple constantly interacting factors, including the deployment of economic resources; in this sense, some states are better suited than others to fulfil their duties. Article 2 of the ICESCR, stresses that states, individually or through cooperation, and to the extent of their capabilities, shall progressively achieve the full realization of the rights within the Covenant.

Taking into consideration the mentioned article, one of the most evident links between substantive states' duties and the climate regime is that they both recognize the principle of common but differentiated responsibilities; which means that all actions that states shall implement to fulfil their duties, arising either from the ICESCR or the UNFCCC, will depend on a country's particular context, including its economic background. However, this could be problematic when addressing climate change from a human rights perspective for various reasons. First, according to the Report on Human Rights and Climate Change by the OHCHR (2009) and the Report on the effects of Climate Change on the full enjoyment of Human Rights elaborated by five different United Nations Special Rapporteurs (UN Special Procedures, 2015), the impacts of climate change, and therefore on the enjoyment of human rights, will be more evident in vulnerable groups, located in poor communities dispersed along developing countries. Consequently, developing countries shall bear the burden of not only employing their limited resources to fulfil their duties by shouldering the creation of laws, policies and institutions to address the issues-possibly not directly caused by them-but also of assuming the remedies for the victims of those human rights violations if a case is brought before a national court. Secondly, the procedural right to a judicial appeal could also be threatened in developing countries, since a great number of legal actions that could potentially arise due to climate change, could eventually lead to a collapse of the domestic judicial system, leaving many victims defenseless. Thus, the lesson here is that, while addressing some categories of human rights within a domestic human rights court is feasible, a heavy burden is allocated to developing countries.

In this context, the Committee on Economic, Social and Cultural Rights, the treaty body of the ICESCR, has said that even if states could claim the lack of resources to fulfil their duties, certain "core 
obligations" are still expected in specific cases, which means that states must demonstrate that they "act in good faith to take such steps" (Committee on ESC Rights, 2015) in order to "distinguish the inability from the unwillingness of a State party to comply with its obligations" (Committee on ESC Rights, 2015). However, the difficulty of complying with this standard is that not all rights will have equal core provisions in a climate change context. For instance, in the milieu of flooding in a developing country, the threshold for setting the core obligation with respect to the right to water and sanitation or food will be lower than, perhaps, the right to housing or health. This demonstrates a relevant issue: that sometimes, human rights courts refrain from developing in depth judgments regarding environmental matters, because courts are "well-suited to safeguard procedural rights, but may lack the resources and expertise, as well as the political mandate, to determine specific levels of environmental protection" (Committee on ESC Rights, 2015).

\section{THEORETICAL AND PRACTICAL CHALLENGES OF USING INTERNATIONAL HUMAN RIGHTS LAW TO AD- DRESS THE EFFECTS OF CLIMATE CHANGE}

The complexity of addressing climate change through a human rights perspective lies in the fact that climate change is a complex system, with numerous and differing repercussions around the world. Floods, droughts, and rising sea levels are all real case scenarios, but it is no easy task to claim with certainty who is the responsible for such catastrophes, and to what extent those victims could be considered in strict rigor to be human rights victims.

Human rights law has some basic principles that are accepted among regional systems: domestic jurisdiction, exhaustion of domestic remedies, and priorities of rights, among others. These principles might be conflictive when trying to apply a human rights approach to climate change effects. As an illustrative example, the rule of the exhaustion of domestic remedies, which allows states to "solve their own internal problems in accordance with their own constitutional procedures before accepted international mechanisms" (Shaw, 2008: 273) can generate delays when victims of climate change may want to pursue justice in regional courts, in the case that their domestic courts fail to respond to their claims. 
However, focusing now on the general duties of states to respect, protect and fulfil human rights from an international perspective, it is worth examining if states are perhaps already taking steps to comply with their international duties within the climate regime by adopting mitigation and adaptation measures through COP decisions-thus satisfying the obligation of the due diligence deemed, according to the International Law Commission, as an obligation of states to "take preventive or minimization measures"; which will not guarantee the total prevention of significant harm to other countries, but will be considered state's "best possible efforts to minimize the risk" (International Law Commission, 2001:154). This obligation resonates with procedural duties by which states are bound regarding human rights. When procedural dutiessuch as access to information, consultations with stakeholders and judicial appeal-are implemented, the risk of committing a human right violation lessens, and the obligation of due diligence is fulfilled. The relevance of this point is that, while trying to address climate change effects through human rights law, states can argue that by adopting COP decisions they are complying with international human rights law, even if the language and perspective of human rights is absent. Here, the legal implication is that a human rights court considering a case in the context of climate change must weigh whether the mitigation and adaptation measures accepted and implemented by a state through a COP negotiation are sufficient to discharge an alleged breach of international human rights law.

Another valid point of discussion is that human rights law was primarily designed for human rights victims under the jurisdiction of a state which breaches its obligations to respect, protect and fulfil human rights. This view is supported by the Bankovic case, where the ECtHR stated that "the case-law of the Court demonstrates that its recognition of the exercise of extra-territorial jurisdiction by a Contracting State is exceptional" (ECtHR, 2001), thus providing a legal hindrance in a climate change context. Moreover, the Court stressed the applicant's point as invalid, by stating that it is incorrect "that anyone adversely affected by an act imputable to a Contracting State, wherever in the world that act may have been committed or its consequences felt, is thereby brought within the jurisdiction of that State" (ECtHR, 2001). Here, the evident consequence is that "if the protection from human rights treaties is dependent upon states acting within their jurisdiction, the danger is that extra-jurisdictional acts can be carried out without responsibility being triggered" (Skogly, 2010; 93), thus freeing countries that emit the most GHGs from any responsibility. 
However, an interesting argument has been identified by John Knox (2009) regarding certain extra-territorial duties of states with respect to human rights in a climate change context. He says that while most rights embedded in the ICCPR and the ICESCR must be safeguarded within each state's jurisdiction, there is an opportunity to argue in favor of small islands states such as the Maldives, whose territories are at risk of total disappearance. Both the ICCPR and the ICESCR enshrine the right to self-determination, which entails the freedom to determine states' own political status and their economic, social and cultural development. Since in theory this right is not subject to a specific jurisdiction, all countries have an obligation to respect the self-determination of their peers. Taking into consideration that, for these vulnerable states, climate change is a threat to the entire existence of their territories, a complete violation of their right to selfdetermination could become a reality. Thus all countries, especially big emitters such as the United States, European Union and China, could be held responsible for not taking preventive measures, and could possibly face human rights complaints within their own jurisdictions.

Here, it goes without saying that "only governments can bring claims against another state for violations of general international law2 (Boyle, 2012: 634), narrowing the scope of application of international human rights law regarding climate change in an inter-state dispute. Additionally, human rights law is established as a mechanism "to address direct entitlements and violations, most often at an individual level, even if some group or collective rights are recognized" (McInerneyLankford, 2013: 233). In this sense, if climate change is a global problem that affects millions of people around the world, then handling it on a case-by-case basis will deter a coordinated response to tackling "extraterritorial effects of domestic actions" (Knox, 2009, 52).

One of the most difficult challenges in addressing climate change through the lens of human rights is to find a logical method to prove causation. Since climate change is a phenomenon that is caused by virtually everyone, it would be extremely complex for a court to deem a particular country responsible for damages or human rights violations in a certain area. And the "multiple states' complicity" does not provide a strong basis of contention within the human rights arena, since "international human rights bodies, whether entrusted to provide binding or non-binding decisions, either hold a state responsible or not responsible" (Harrington, 2007, 527). 
Also, as the Report of the OHCHR (2009) on climate change and human rights states: "global warming is often one of several contributing factors to climate change related effects", thus rendering it almost "impossible to establish the extent to which a concrete climate change-related event with implications for human rights is attributable to global warming".

Finally, most of the devastating climate change negative impacts will occur in the future, in the scenario in which countries surpass their national GHG emissions quota and a global temperature of $2^{\circ} \mathrm{C}$ is reached.

\section{CLIMATE CHANGE AND HUMAN RIGHTS IN DOMESTIC AND REGIONAL JURISDICTION}

From what has been stated so far, a human rights approach to climate change in strict legal rigor may face numerous challenges and imply a disparate burden for developing countries and vulnerable groups. However, there are certain cases in which national and regional litigation, along with a creative use of national/regional law, have the potential to achieve a strong legal basis in countering the reluctance of states to implement preventive measures that protect and fulfil human rights.

What should be considered, however, is that regional courts and tribunals do have a saying with regards climate change; although within the boundaries of a specific international convention. The role they could play might expand such confines, however, thus contributing to "a change of consciousness" (Sands, 2016). This view should not be embraced without its caveats, though, since every advancement that might be driven by courts is anchored by the rigid weight of principles and processes.

Let us not forget that a general principle of international human rights law is that claimants should exhaust national remedies, as a "method of permitting states to solve their own internal problems in accordance with their own constitutional procedures before accepted international mechanisms can be invoked" (Shaw, 2008: 273), which means that human rights cases that draw upon environmental issues, or more specifically, upon climate change effects, will be contended on the same factual and legal arguments. For instance, if the right to life is violated due to the failure of a state to take preventive measures 
in the context of an environmental catastrophe, claimants seeking justice will take legal actions within the negligent state's jurisdiction; if the state's administrative or judicial system is not able to provide for integral redress, the claimants, depending on their regional human rights system, can file a petition before a regional human rights court. This has been the rationale behind several emblematic cases in different regional human rights systems, where environmental harm has triggered the use of human rights law.

The Report by the OHCHR on Human Rights and Climate Change (2009) dedicates an entire section to national obligations regarding climate change, which includes fundamental insights regarding the role of states as the first protectors of human rights, and the scope of this approach as a mechanism for providing effective measures to address the impacts of climate change. In addition, it draws upon the role of the state as an accountable entity through which citizens can file their claims when acts or omissions fail to protect them against loss of the enjoyment of human rights, due to climate change effects.

A clear real case example, which could be transposed to other analogous cases related to climate change, is the Budayeva v. Russia case before the European Court of Human Rights (2008), which stressed that no justification was found for the state's failure to fulfil its duty for land-planning and emergency planning in the face of foreseeable environmental risks, leading to the death of Vladimir Budayeva due to a mudslide. The Court deemed that Russia failed to implement its "positive obligation to establish a legislative and administrative framework designed to provide effective deterrence against threats to the right to life as required by Article 2 of the Convention." (ECtHR, 2008). When interpreting this case in the context of climate change, it is important to remember that while certain states are less responsible in contributing to the GHG emissions that are the primordial cause of climate change threats, this is no excuse for refraining from protecting individuals against those threats; and if a lack of resources may be a problem in achieving this, the standard of due diligence in this regard is still to seek assistance from other states (Knox, 2009, 37).

Adapting this duty to an extraterritorial context, "human rights law still imposes duties on states to address the internal effects of climate change and constrain their possible responses to "” (Knox, 2009, 6). This internal duty shall also be addressed in the case of transboundary claimants, affected by the pollution of a neighboring state, who can 
make use of the national redress available and "resort to international or regional human rights law when necessary to compel the polluting state to enforce its own court orders or laws" (Boyle, 2012, 39).

The strategy of using domestic courts to seek human rights redress, by arguing that climate change is also a determining factor at the core of the dispute, is an evolving practice, particularly when domestic courts are heterogeneous enforcers of international law in general and human rights matters in particular; this providing that their interpretation can solidify or unify assorted international norms (Cantú Rivera, 2015, 318), including those where a link between climate change and human rights is evident.

One emblematic case that grapples with the failure of the duty of environmental care by a national government in respect to a foreign private company and involves encroachment on the human rights of local communities is Gbemre v. Shell Petroleum Development Company of Nigeria Ltd et al.. Here, while the case was focused mainly on the localized harms arising from gas flaring, emitted by the Nigerian subsidiary company of Shell Oil, the applicants for the national recourse included climate change as a resultant effect of gas flaring (Osofsky, 2010: 191). The judge ordered that the respondents take immediate steps to stop the further flaring of gas in the applicants' community (Gbemre vs Shell, 2005).

A recent and widely-acclaimed case is that of Urgenda Foundation $v$. Government of the Netherlands, in which the Dutch District Court, on June 2015, "held that the Dutch government has a duty of care towards the plaintiffs to mitigate the likelihood of dangerous anthropogenic climate change" (Van Zeben, 2015, 341). The difference between the Gbemre v. Shell case and this one, is that here the court ordered the "reduction of GHG emissions for reasons other than statutory mandate" (Van Zeben, 2015, 347), thus "establishing an infringement of the duty of care of the Dutch government, taking into account that a foreseeability and likelihood of damage could be deemed, considering the high risk that climate change entails; thus holding that mitigation is essential in preventing climate change" (Van Zeben, 2015, 348).

This climate litigation trend in some countries has increased since Urgenda, even in countries that produce the majority of GHG, like the United States. For instance, in Kelsey Cascadia Rose Juliana, et al., v. United States of America, et al, a group of 21 young plaintiffs 
and environmental advocates filed a constitutional climate lawsuit before the U.S. District Court for the District of Oregon in 2015 against the United States, President Barack Obama, and numerous executive agencies, including the Environmental Protection Agency (EPA), alleging deliberate omissions in controlling atmospheric CO2 concentrations (Steiner, 2017).

The plaintiffs also contend a violation of their constitutional due process and public trust rights by the federal government and demand the deployment of a plan to cut down carbon emissions (Scanlan K., n.d.).

The case was firstly reviewed by Magistrate Judge Thomas F. Coffin, who in April 2016, denied the intervenors' and government's motion to dismiss, granting the plaintiffs a leeway to pursue their case under judiciary proceedings. Moreover, Magistrate Coffin asserted that courts should "evaluate the constitutional parameters of the action or inaction taken by the government. This is especially true when such harms have an alleged disparate impact on a discrete class of society." (U.S. Magistrate Judge Thomas Coffin, 2016).

In addition, the Magistrate did acknowledge the question of separation of powers, in which the judiciary might be entering into the domains of the executive power by way of proposing public policies, a problem which resonates with the shortcoming discussed above about how ill-equipped courts might be to develop detailed environmental policies. To this, Coffin admitted that drawing specific regulations might transcend the expertise of the court; nonetheless, it can "direct the EPA to adopt standards that prevent the alleged constitutional harm to the youth and future generation plaintiffs, should plaintiffs prevail in demonstrating such is possible" (U.S. Magistrate Judge Thomas Coffin, 2016).

Months later, in November 2016, Oregon District Judge Ann Aiken, adopted Coffin's Findings and Recommendation in the same case pursuant to Federal Rule of Civil Procedure, meaning that the defendants' and intervenors' motion to dismiss were once again denied. Judge Aiken, by stating that this was "no ordinary lawsuit", posited that the "right to a climate system capable of sustaining human life is fundamental to a free and ordered society. Just as marriage is the "foundation of the family," a stable climate system is quite literally the foundation "of society" (Judge Ann Aiken, 2016). 
Finally, Judge Aiken concluded that allegations regarding the dissatisfaction of plaintiffs, emerging from inadequate relief through citizen suits brought under environmental laws, might be accurate; but that is not the point. The point is to accept that the current action is an atypical environmental case, which is based on the presumption that "defendants' actions and inactions - whether or not they violate any specific statutory duty - have so profoundly damaged our home planet that they threaten plaintiffs' fundamental constitutional rights to life and liberty" (Judge Ann Aiken, 2016). With Judge Aikens' ruling, by rejecting the motion to dismiss, the case can move forward to discovery, summary judgment, and trial (Scanlan K., n.d.).

In the same vein, as in Juliana v. United States, in 2014, eight young citizens from Washington State filed a case before King County Superior Court challenging the Washington Department of Ecology's denial of their request to limit GHG emissions in Washington, according to science-based recommendations to protect oceans and climate system (Our Children's Trust, 2014). In June 2015, King County Superior Court Judge Hollis Hill issued her decision in Zoe \& Stella Foster v. Washington Department of Ecology, ordering the Washington Department of Ecology to reconsider the petition for GHG reductions (Our Children's Trust, 2015).

In December 2016, Judge Hollis Hill ruled that the young plaintiffs can again move forward, now with a constitutional climate rights claim that adds the state of Washington and its governor Jay Inslee as defendants. Judge Hill's ruling follows an earlier hearing at which the plaintiffs asked the court to find the Department of Ecology in contempt for failing to fulfil orders to protect the constitutional rights of young people and future generations to a stable climate (Our Children's Trust, 2016). Notwithstanding, Judge Hill denied the motion for contempt and she did grant the young citizens' request to add claims that the state of Washington and Governor Inslee violated the Washington state constitution and the public trust doctrine, so the young people will "have their day in court" (Honorable Hollis R. Hill, 2016). ${ }^{34}$

34 The Judge further ordered sua sponte that petitioners are granted leave to amend their petition to therein plead a complaint for declaratory judgment or other action, and that the Department of Ecology is violating their rights to a healthy environment, alleging "the emergent need for coordinated science-based action by the State of Washington to address climate change before efforts to do so are too costly and too late" (Honorable Hollis R. Hill, 2016). 
Furthermore, within this decision, the cross-fertilization of judgements should be taken into consideration at both the Federal and international levels. Judge Hill cited the precedents in Juliana, et al. v. United States of America, et al.: namely the assertion regarding governmental actions or omissions that might substantially damage the climate system in a way that will dramatically alter the planet's ecosystem and human life, which should be interpreted as a claim for due process violation (Honorable Hollis R. Hill, 2016). In that vein, the Urgenda case was also referred to in a footnote, where it was noted that an evaluation of the constitutional parameters of the actions or inactions taken by the government was required from courts (Honorable Hollis R. Hill, 2016).

In the Ashgar Leghari v. Federation of Pakistan case in 2015, a farmer challenged the inaction of the Federal Government of Pakistan and of the Regional Government of Punjab in light of the challenges and vulnerabilities associated with climate change. The plaintiff argues that despite the National Climate Change Policy and the Framework for Implementation of Climate Change Policy, progress is absent, thus increasing the threats to the Pakistan's water, food and energy security due to climate change, and violating the fundamental right to life under article 9 of the Pakistani Constitution (Syed Mansoor Ali Shah, 2015).

The Lahore High Court declared that climate change has led to dramatic alterations in the planet's climate system, and that in Pakistan in particular, climate effects like heavy floods and droughts are a clarion call for the protection of the fundamental rights of its citizens, especially, "the vulnerable and weak segments of society who are unable to approach this Court" (Syed Mansoor Ali Shah, 2015).

The Court, following the judgments in the United States mentioned above, invoked public trust doctrine as a principle that should be constitutionally read alongside several fundamental rights, like the right to life, which includes the right to a healthy and clean environment and the right to human dignity. Therefore, the Court deemed that delay in the state's implementation of Climate policies offends the fundamental rights of its citizens, which must be safeguarded (Syed Mansoor Ali Shah, 2015).

As a result, the Court ordered all ministries, departments and authorities to name a climate change point person to work with the Ministry of Climate Change and implement Climate Change policies. 
To monitor progress, the Court required the creation of a Climate Change Commission comprised of ministries, NGOs and technical experts (Syed Mansoor Ali Shah, 2015).

Even though the above-mentioned cases were to some extent successful in terms of the judges' usage of public trust doctrine and human rights in favour of the plaintiffs, not all domestic litigation cases are decided homogenously. For instance, in 2015, Saúl Luciano Lliuya, a Peruvian farmer from the Andes, filed a lawsuit against the German-based energy company RWE at the Regional Court in Essen (Germany). The lawsuit argues that the Essen-based company is partly responsible for glacial melting in the Andes and thus also for the likely amount of flood waves that might damage the plaintiff's house, which lies at the foot of the mountains (Germanwatch, 2015). The claimant is requesting a payment from RWE that will be invested in safety adaptation measures at the glacial lake Palcacocha, situated above Huaraz, the city affected by climate change where Luciano lives. The payment requested is proportional to the company's contribution to climate change (Germanwatch, 2015).

However, a year after the civil lawsuit was filed, the Regional Court of Essen dismissed the Peruvian's lawsuit by arguing, inter alia, a lack of "legal causality", even though there may be a "scientific causality" (Germanwatch, 2016). This resonates with the challenges that courts might find in determining a causality link between the negative effects of climate change on people and the environment, and the emitters. Though this case did not favour the claimant at the first stage, in January 2017 Mr. Luciano filed an appeal before the Higher Regional Court Hamm demanding a review based on scientific facts that could be steered towards defining legal causality, although the outcome has yet to be seen (Germanwatch, 2017).

As a concluding remark, the potential of bringing a successful claim through litigation before domestic and regional courts, encompassing a human rights redress against the threats of climate change is selfevident, considering that states have stronger provisions under their own regional and domestic jurisdictions, whose scope is better suited for developing progressive precedents than those from international human rights frameworks. It must be noted, however, that heterogeneous methods to interpret the law are an inherent trait among legal systems across states, therefore, not all rulings will favour climate plaintiffs, and negative precedents are always a plausible outcome. 


\section{PROBLEMS AS SOLUTIONS: REDD+ AS A THREAT TO HUMAN RIGHTS}

Apart from the implications that climate change has for the enjoyment of human rights in general, vulnerable groups like women, children and indigenous peoples will face a larger burden of risks regarding the impacts on their livelihoods (UN Special Procedures, 2015). As previously mentioned, the Inuit people filed a petition to the Inter-American Commission of Human Rights regarding the violation of their collective and individual rights, linked to the effects of climate change.

The Inuit petition is a perfect example of the direct brunt that indigenous peoples must face regarding the effects of climate change. However, the impacts on their collective rights can also be felt from other sources interrelated with climate change, and it is the mitigation and adaptation measures that the COP has endorsed so far. It is interesting to note that some COP decisions aimed at tackling climate change can also threat human rights, as in the case of the implementation of the REDD+ mechanism.

In addition to the "universal" human rights instruments, such as the ICCPR and the ICESCR, indigenous and tribal peoples are entitled to special international treaties, with the most relevant being the International Labour Organization 169 Convention concerning Indigenous and Tribal Peoples in Independent Countries (ILO 169) and the United Nations Declaration on the Rights of Indigenous Peoples (UNDRIP) (not legally binding). Both normative frameworks include substantive and procedural rights that state parties must safeguard. Special consideration must be given to the rights to management and conservation of the resources within their territories, the right to free, prior and informed consent, and the right to "protect and preserve the environment of the territories they inhabit" (ILO 169, 1989).

However, and given the repercussions of the so-called "fragmentation of international law", the climate regime had not always taken human rights into consideration as a source for its law-making procedures. The creation of the REDD+ mechanism is a case in point (Jodoin, 2016: 166).

Article 4 of the UNFCCC stresses the commitments of all parties to the convention to "[p]romote and cooperate in the development, 
application and diffusion, [...] of practices and processes that control, reduce or prevent" GHG emissions in the agriculture and forestry sectors while also promoting and cooperating in "sustainable management, [...] conservation and enhancement [of] forests [...], as well as other terrestrial [...] ecosystems."

Despite this provision, which clearly envisages the protection of forests as reservoirs and carbon sinks, it was not until 2005, when Papua New Guinea and Costa Rica -two developing countries which are deemed as rich in forest resources-, jointly submitted a proposal acknowledging the "climatic importance of deforestation" and prompting the necessity of addressing "the significant emissions resulting from deforestation" and its implications for climate change (UNFCCC, 2005).

The 2005 proposal was at last backed by a COP decision during its thirteenth session in Bali in 2007, where parties were invited and encouraged to "strengthen and support ongoing efforts to reduce emissions from deforestation and forest degradation on a voluntary basis", by providing technical assistance to developing countries to gather information on emissions from deforestation and forest degradation, and addressing the drivers of deforestation (UNFCCC, 2007). This initiative, which was eventually called REDD+, is now largely seen as an opportunity for developing countries to earn incentives for the conservation of their forests, while combating climate change (Recio, 2014: 38).

REDD+ is a mechanism that involves modification of domestic legislation regarding forest and land law in order to establish an enabling normative framework as basis. However, these modifications could eventually disrupt traditional forest-based livelihoods, thus threatening the human rights of indigenous peoples (Savaresi, 2013: 5).

For instance, in 2008 and 2009, several Indigenous Peoples Organizations and NGOs mobilized during COP negotiations to advocate the upholding of the rights of Indigenous Peoples and local communities in the context of REDD+. These efforts led to the inclusion of a rights-based language referring to the importance of Indigenous Peoples' rights in further COP discussions (Jodoin, 2016: 168). The first was the crystallization of the importance of Indigenous Peoples' rights in the Cancún Agreements in 2010, by way of developing environmental and social safeguards. However, all decisions made up until now fail to appropriately encompass the rights enshrined 
in international or regional human rights instruments, including UNDRIP and ILO 169 (Jodoin, 2016, 172).

This international legal vacuum might result in careless implementation of REDD+ projects in local communities, especially since there will be countries that have not ratified some of the international human rights instruments, and thus are not obliged to comply with their provisions. If human rights protections are also missing from REDD+ policies, there is no guarantee that states or private actors will not violate indigenous peoples' rights. Said violations could include obstacles to accessing land or territories, land evictions, and omission of the right to free, prior and informed consent. For example, the UN Committee on the Elimination of Racial Discrimination has recommended that Indonesia re-examine regulations adopted to carry out REDD+ activities, to ensure that they respect the rights of indigenous peoples to possess, develop, control, and use their communal lands (Savaresi, 2013).

Here, a good opportunity to safeguard the rights of local communities threatened by conservation mechanisms designed to mitigate the effects of climate change, is to ensure that any domestic legislative modification includes provisions regarding the compliance by the state with human rights obligations, which may include the protection of indigenous territories and the duty to comply with free, prior and informed consent of indigenous peoples or forest dwellers in advance making decisions that could affect them directly.

\section{CONCLUSION}

The Paris Agreement is the outcome of a long, heated and global battle to tackle climate change. Although its results may not be sufficient to grapple with the effects of climate change, the fact that human rights are included at least in its preamble, and that specific references to gender and indigenous peoples are mentioned in its operative section, reflects the importance of human rights discourse as a compelling narrative that will be included in the future climate regime discussions.

However, from what has been discussed in this paper, addressing climate change through the lens of human rights is still a work in progress. Despite the advances in setting cutting-edge precedents, domestic and 
some regional human rights courts still face colossal theoretical and practical challenges, which could be surmounted by the use of creative legal thinking and reliance upon scientific facts, as demonstrated with Urgenda. Moreover, tackling the problem by all means necessary could entail externalities, as evidenced with the case of REDD+ and the human rights of local communities-reaffirming the fact that even climate change solutions must include human rights safeguards.

\section{REFERENCES}

Bodansky, D. (2010). Introduction: Climate Change and Human Rights: Unpacking the Issues, Volume 38: Number 3, Georgia Journal of International and Comparative Law. 511.

Boyle, A. (2012). Human Rights and the Environment: Where next?, 23:3 The European Journal of International Law. 613.

Cantú Rivera, H. F. (2015). Business \& Human Rights: From a 'Responsibility to Respect' to Legal Obligations and Enforcement. In J. L. Cernic \& T. Van Ho (Eds.), Human Rights and Business: Direct Corporate Accountability for Human Rights (303-322). Wolf Legal Publishers.

Fredman, S. (2008). Human Rights Transformed: Positive Rights and Positive Duties (Oxford University Press), at 67.

General Comment on The Right to Water, Committee on Economic, Social and Cultural Rights (UN Doc. E/C.12/2002/11, 20 January 2003). 40.

Germanwatch. (2015). Peruvian farmer sues German utility RWE over dangers related to glacial melting [Environmental Blog]. Retrieved from: https://germanwatch.org/en/11302

Germanwatch. (2016). Regional Court dismisses climate lawsuit against RWE - Claimant likely to appeal [Environmental Blog]. Retrieved from: https://germanwatch.org/en/13234 
Germanwatch. (2017). Climate Suit against RWE: Peruvian Mountain Guide Will Appeal [Environmental Blog]. Retrieved from: https://germanwatch.org/en/13438

Haas, M. (2014). International Human Rights: A Comprehensive Introduction, 2nd ed. (Routledge).

Harrington, J. (2007). Climate Change, Human Rights, and the Right to be Cold, 18:3 Fordham Environmental Law Journal. 513.

Honorable Hollis R. Hill. Z. and Stella Foster, et al., v. (2016). Washington Department of Ecology, No. 14-2-25295-1 SEA (Court of the State of Washington in and for the County of King).

Human Rights Council Resolution 10/4, Human Rights and Climate Change (UN Doc. A/HRC/10/29, 9 November 2009), Report of the Human Rights Council on its tenth session. 11.

Human Rights Council Resolution 18/22, Human Rights and Climate Change (UN Doc. A/HRC/RES/18/22, 22 October 2012), Report of the Human Rights Council on its eighteenth session. 55.

Human Rights Council Resolution 26/27, Human Rights and Climate Change (UN Doc. A/HRC/26/2, 11 December 2014), Report of the Human Rights Council on its twenty-sixth session.

Human Rights Council Resolution 26/27, Human Rights and Climate Change, Promotion and protection of all human rights, civil, political, economic, social and cultural rights, including the right to development (UN Doc. A/HRC/26/L.33, 23 June 2014), 3.

Human Rights Council Resolution 29/15, Human Rights and Climate Change (UN Doc. A/HRC/29/2, 25 November 2015), Report of the Human Rights Council on its twenty-ninth session.

Human Rights Council Resolution 7/23, Human Rights and Climate Change (UN Doc. A/HRC/7/78, 14 July 2008), Report of the Human Rights Council on its seventh session. 65.

Humphreys, S. (2009). (ed.), Human Rights and Climate Change (Cambridge University Press) 
Jodoin, S. (2016). The human rights of Indigenous Peoples and forest-dependent communities in the complex legal framework for REDD+. In Research Handbook on REDD-Plus and International Law. Cheltenham, UK: Edward Elgar Publishing, Inc. Retrieved from // www.elgaronline.com/9781783478309.00019.xml

Judge Ann Aiken. Kelsey Cascade Rose Juliana et al. v. The United States of America et al. (United States DIstrict Court for the District of Oregon eugene Division 10 November 2016)

Knox, J. (2000). Climate Change and Human Rights Law, 50:1 Virginia Journal of International Law. 163.

M. N. Shaw, International Law, 6th edition (Cambridge, 2008).

McInerney-Lankford, S. (2013). Human Rights and Climate Change: Reflections on International Legal Issues and Potential Policy Relevance, M.B. Gerrard and G.E. Wannier (eds.), Threatened Island Nations: Legal Implications of Rising Seas and a Changing (Cambridge University Press). 195.

McInerney-Lankford, S. Darrow, M. and Rajamani, L. (2011). Human rights and climate change: a review of the international legal dimensions. 8.

Moyn, S. (2010). Personalism, Community, and the Origins of Human Rights, in S.L. Hoffmann (ed.), Human Rights in the Twentieth Century. Cambridge University Press.

Okowa, P. (2000). State Responsibility for Transboundary Air Pollution in International Law (Oxford University Press).

Osofsky, H. (2010). Climate change and environmental justice: reflections on litigation over oil extraction, and rights violations in $\mathrm{Ni}$ geria, 1:2 Journal of Human Rights and the Environment.

Our Children's Trust. (2014). Youth appeal Washington Department of Ecology's decision to deny their climate change petition for rulemaking (3). Washington: Our Children's Trust. Retrieved from: https://static1. squarespace.com/static/571d109b04426270152febe0/t/57608172f8baf3e5ddec950c/1465942386906/WA.PetitionForReview.PressRelease.pdf 
Our Children's Trust. (2015). Washington State Youth Win Unprecedented Decision in their Climate Change Lawsuit (3). Washington: Our Children's Trust. Retrieved from https://static1.squarespace. com/static/571d109b04426270152febe0/t/576080c61bbee08251f2834b/1465942214961/15.06.24WADecisionPR.pdf

Our Children's Trust. (2016). Judge allows youth constitutional climate rights case to move forward against state of WA and Gov. Inslee (3). Washington: Our Children's Trust. Retrieved from https://static1. squarespace.com/static/571d109b04426270152febe0/t/58598d7dd1758e6ea45711d3/1482263935834/2016.12.20-WA+ATL+Constitutional+Case+NR.pdf

Pachauri, R.K. and Meyer, L.A. (2014). (eds.), Climate Change 2014: Synthesis Report - Contribution of Working Groups I, II and III to the Fifth Assessment Report of the Intergovernmental Panel on Climate Change.

Pachauri, R.K. and Reisinger, A. (2007). (eds.), Climate Change 2007: Synthesis Report - Contribution of Working Groups I, II and III to the Fourth Assessment Report of the Intergovernmental Panel on Climate Change.

Petition to the Inter American Commission on Human Rights seeking relief from violations resulting from global warming caused by acts and omissions of the United States, Submitted by Sheila Watt-Cloutier, with the support of the Inuit Circumpolar Conference, on behalf of all Inuit of the arctic regions of the United States and Canada (December 7 2005), found at: http://www.inuitcircumpolar.com/ uploads/3/0/5/4/30542564/finalpetitionicc.pdf

Recio, M.E. (2014). The Warsaw Framework and the Future of REDD+. 24:1 Yearbook of international Environmental Law.

Report of the Office of the United Nations High Commissioner for Human Rights (OHCHR) on the Relationship between Climate Change and Human Rights (UN Doc. A/HRC/10/61, 2009).

Report of the Special Rapporteur on adequate housing as a component of the right to an adequate standard of living and on the right to non-discrimination in this context (UNGA Doc. A/64/255, 6 August 2009), note by the Secretary-General on the sixty-fourth session of 
the General Assembly; Report of the Independent Expert on the issue of human rights obligations relating to the enjoyment of a safe, clean, healthy and sustainable environment, John H. Knox (UNGA Doc. A/ HRC/25/53/Add.1, 8 April 2014), Human Rights Council on the twenty-sixth session;

Sands, P. (2016). Climate Change and the Rule of Law: Adjudicating the Future in International Law*. Journal of Environmental Law, 28(1), 19-35. https://doi.org/10.1093/jel/eqw005

Savaresi, A. (2013) 'REDD+ and Human Rights: Addressing Synergies between International Regimes' 18:3 Ecology and Society. 5.

Scanlan K., M. (n.d.). Juliana v. United States: Does the Constitution Guarantee a Livable Planet for Our Kids? [School of Law Blog]. Retrieved 4 May 2017, from http://vjel.vermontlaw.edu/topten/juliana-v-united-states-constitution-guarantee-livable-planet-kids/

Skogly, S. (2010). Extraterritoriality: Universal human rights without universal obligations, in S. Joseph and A. McBeth (eds.), Research Handbook On International Human Rights Law. (Edward Elgar). 71.

Special Procedures of the United Nations Human Rights Council, 'The Effects of Climate Change on the Full Enjoyment of Human Rights' (2015), at para. 11, found at: http://www.thecvf.org/wp-content/uploads/2015/05/humanrightsSRHRE.pdf

Steiner, G. (2017). No Ordinary Lawsuit: Juliana v. United States is a Landmark Precedent for Climate Change Legislation [Law Blog]. Retrieved 4 May 2017, from http://www.jurist.org/forum/2017/01/ Gabriela-Steier-juliana-v-united-states.php

Syed Mansoor Ali Shah. (2015). Ashgar Leghari v. Federation of Pakistan, No. W.P. No. 25501 (Lahore High Court).

U.S. Magistrate Judge Thomas Coffin. Kelsey Cascade Rose Juliana et al. v. The United States of America et al. (United States DIstrict Court for the District of Oregon 4 August 2016).

United Nations Office of the High Commissioner of Human Rights, Status of Ratification Interactive Dashboard, Status of Ratification of 
the International Covenant on Economic, Social and Cultural Rights, found at: <http://indicators.ohchr.org/>.

Van Zeben, J. (2015). Establishing a Governmental Duty of Care for Climate Change Mitigation: Will Urgenda Turn the Tide? 4:2 Transnational Environmental Law. 339,. 340, 341.

Recibido: 08/01/2017

Aprobado para publicación: 27/05/2017

Juan Auz (LLB, LL.M): Abogado, ex Director Ejecutivo de la Fundación Pachamama y co-fundador de Terra Mater. Actualmente se desempeña como investigador invitado en el Instituto de Investigación de Impacto Climático de Potsdam en Alemania. Especialista en Derecho Ambiental Internacional y Cambio Climático por la Universidad de Edimburgo en Escocia y miembro de la Comisión Mundial de Derecho Ambiental de la UICN. Cuenta con experiencia trabajando en Derechos Humanos y Ambiente, con un enfoque particular en las comunidades locales y los pueblos indígenas.

Correo electrónico: juangauz@gmail.com 